\title{
THE CALEDONIAN NAPPES OF KRONPRINS CHRISTIAN LAND, EASTERN NORTH GREENLAND
}

\author{
John M. Hurst and W. S. McKerrow
}

The earliest geological reconnaissance work in Kronprins Christian Land concerned with the Caledonian nappes was that of Nielsen (1941). Subsequently, Fränkl (1954, 1955) published maps of selected areas and a greatly simplified map of the central part of Kronprins Christian Land between Marmorvigen, Centrum Sø, and Romer Sø (fig. 4). Haller $(1970,1971)$ studied Kronprins Christian Land from the air as part of a larger operation in East Greenland. His conclusions concerning the nappes followed the work of Fränkl (1954, 1955).

The primary aims of the 1980 field season were to remap the clastic sediments contained on the Caledonian nappes, to establish a detailed stratigraphy on each nappe and to correlate between each nappe and the platform sediments.

\section{The nappes}

Fränkl $(1954,1955)$ considered that all the sediments occurring west of the Proterozoic sandstones and east of the Lower Palaeozoic platform carbonate rocks (fig. 4) belonged essentially to one huge nappe, which he termed the Main Nappe. On this nappe Fränkl $(1954,1955)$ recognised a stratigraphy which from below is: Stenørkenen phyllites $(+1000$ $\mathrm{m})$; Sydvejdal marbles with chloritic shales $(100-400 \mathrm{~m})$; Taagefjeldene greywackes $(+700$ $\mathrm{m}$ ) with layers of alum shales $($ c. $150 \mathrm{~m})$; Rivieradal sandstones (1000-2000 m); Ulvebjerg sandstones and tillites (30-35 m); red Campanuladal limestones $(150 \mathrm{~m})$ and Fyns Sø dolomites $(250 \mathrm{~m})$. As the Campanuladal limestones and Fyns S $\varnothing$ dolomites were thought to be of late Precambrian age, the thick clastic succession which they conformably overlie was also assumed to be of a similar age.

Our mapping indicates three major nappes in Kronprins Christian Land; two are south of Romer Sø (fig. 4) and the other is confined to Finderup Land in the north of the area.

(1) The Finderup Land Nappe to the north. Late Precambrian sequences of stromatolitic limestone and clastics of the Campanuladal Formation and deformed stromatolitic dolomite of the Fyns Sø Formation are overlain by Cambrian sandstones with Skolithos and bioturbated siltstones of the Kap Holbæk Formation (fig. 5). This nappe was not recognised by Fränkl (1954). He probably only saw its southern margin and thus referred it to his Main Nappe;

(2) The Vandredalen Nappe of central and southern Kronprins Christian Land. The nappe consists of a thick sequence of turbidites (Rivieradal sandstones of Fränkl, 1954, 1955) overlain by sands, silts, variegated shales, silts with red limestones (in part Campanuladal Formation) and stromatolitic dolomites (Fyns Sø Formation) (fig. 5). The stratigraphic 


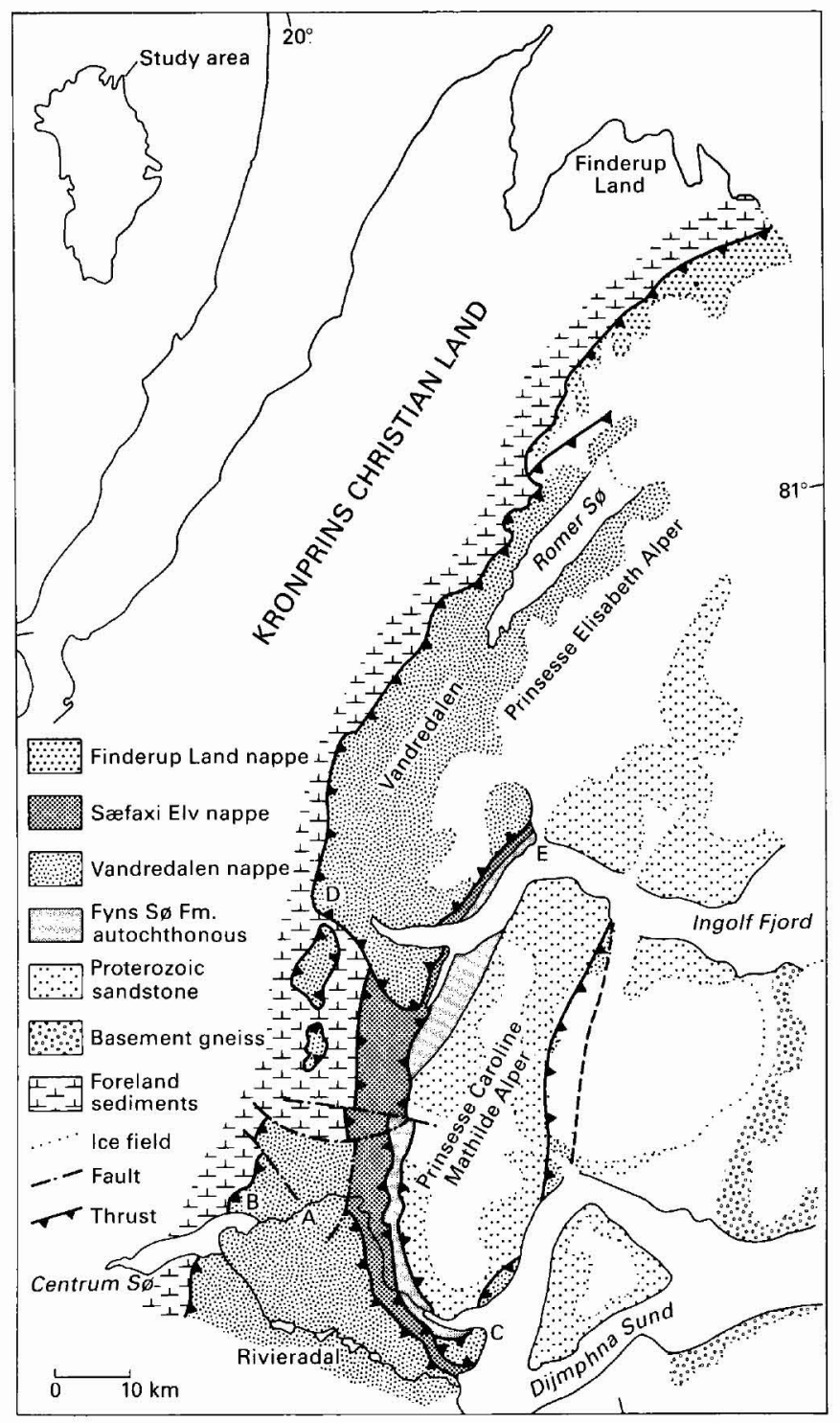

Fig. 4. Simplified geological map of Kronprins Christian Land, North Greenland, showing the distribution of the Caledonian nappes. Sæfaxi Elv (A), Drømmebjerg (B), Marmorvigen (C), Nøglefjeldet (D), Hjørnegletscher (E).

sequence is well exposed on Drømmebjerg (B, fig. 4), on Nøglefjeldet (D, fig. 4) and other hills west of Vandredalen. Basal turbidites of the Rivieradal sandstones also occur on a higher nappe at Marmorvigen (C, fig. 4) and similar silty turbidites may be on separate nappes in northern Kronprins Christian Land. This nappe corresponds to the Main Nappe of Fränkl $(1954,1955)$. Two main conglomerate beds occur within the Rivieradal turbidites; they are mass flow deposits possibly derived from similar conglomerates seen in situ above the Proterozoic sandstones at Marmorvigen and Hjørnegletscher (C \& E, fig. 4). Both the deep water mass flow conglomerates and the shallow water conglomerates contain 95-98 
per cent rounded quartzite clasts and $2-5$ per cent rounded dolerite clasts, indicating derivation from the Proterozoic sandstones. They are not tillites as Fränkl thought.

(3) The Safaxi Elv Nappe in south-east Kronprins Christian Land. A sequence of dolomites with sandstone fissures which have been referred to the 'Danmarks Fjord dolomite' (Fränkl, 1954, 1955) are overlain by Ordovician to ?Silurian black limestones and limy shales of Fränkl's $(1954,1955)$ 'Centrum limestone' unit. In the foreland to the west these two units have been revised by Peel et al. (this report).

In addition, several complex imbricate zones occur at the base of these large nappes; these are exposed along both the eastern and western margins of the nappe outcrops. If the deformation associated with these imbricate zones is due to the nappes, it is consistent with westerly movement of the nappes in the southern part of Kronprins Christian Land, and with north-westerly movement of the Finderup Land Nappe in the north.

\section{Stratigraphy and correlation}

The stratigraphic sequence (fig. 5) in the large nappes and on the Proterozoic sandstones to the east can only be correlated by:

(1) The lithological correlation of the stromatolitic dolomites of the Fyns Sø Formation which are known to be late Precambrian on the platform to the west.

(2) The presence of Skolithos and bioturbated silts which suggest that the uppermost beds of the Finderup Land Nappe are Lower Palaeozoic, and perhaps equivalent to the Lower Cambrian Kap Holbæk Formation of Danmark Fjord.

(3) The presence of Ordovician and ?Silurian fossils in the 'Centrum limestone' of the Sæfaxi Elv Nappe.

(4) The petrographic similarities between the basal lenticular conglomerates resting on the Proterozoic sandstones and those within the Rivieradal turbidites.

(5) The presence of Proterozoic, probably Late Rhiphean acritarch assemblages in the Rivieradal turbidites (G. Vidal, personal communication, 1981).

While none of these individually provide definite age correlations, we believe that together they indicate the correlations suggested in fig. 5 .

Fränkl $(1954,1955)$ named several phyllite, greywacke, sandstone and carbonate units and considered several nappes were present, constituting his Main Nappe, i.e. the Vandredalen Nappe. However, our mapping indicates that all the late Precambrian beds below the Campanuladal Formation on this nappe are part of a single turbidite, mud, sand and conglomerate unit on a single nappe, which contains several areas of low angle isoclinal folds. The upper unit of resedimented conglomerate on the Vandredalen Nappe was wrongly interpretated as a tillite by Fränkl $(1954,1955)$.

Fränkl $(1954,1955)$ recognised the Kap Holbæk Formation below the 'Danmarks Fjord dolomite' in Sæfaxi Elv, at the base of our Sæfaxi Elv Nappe. Our investigations suggest that Fränkl mistook sandstone fissures in the 'Danmarks Fjord dolomite' for the Kap Holbæk Formation. 


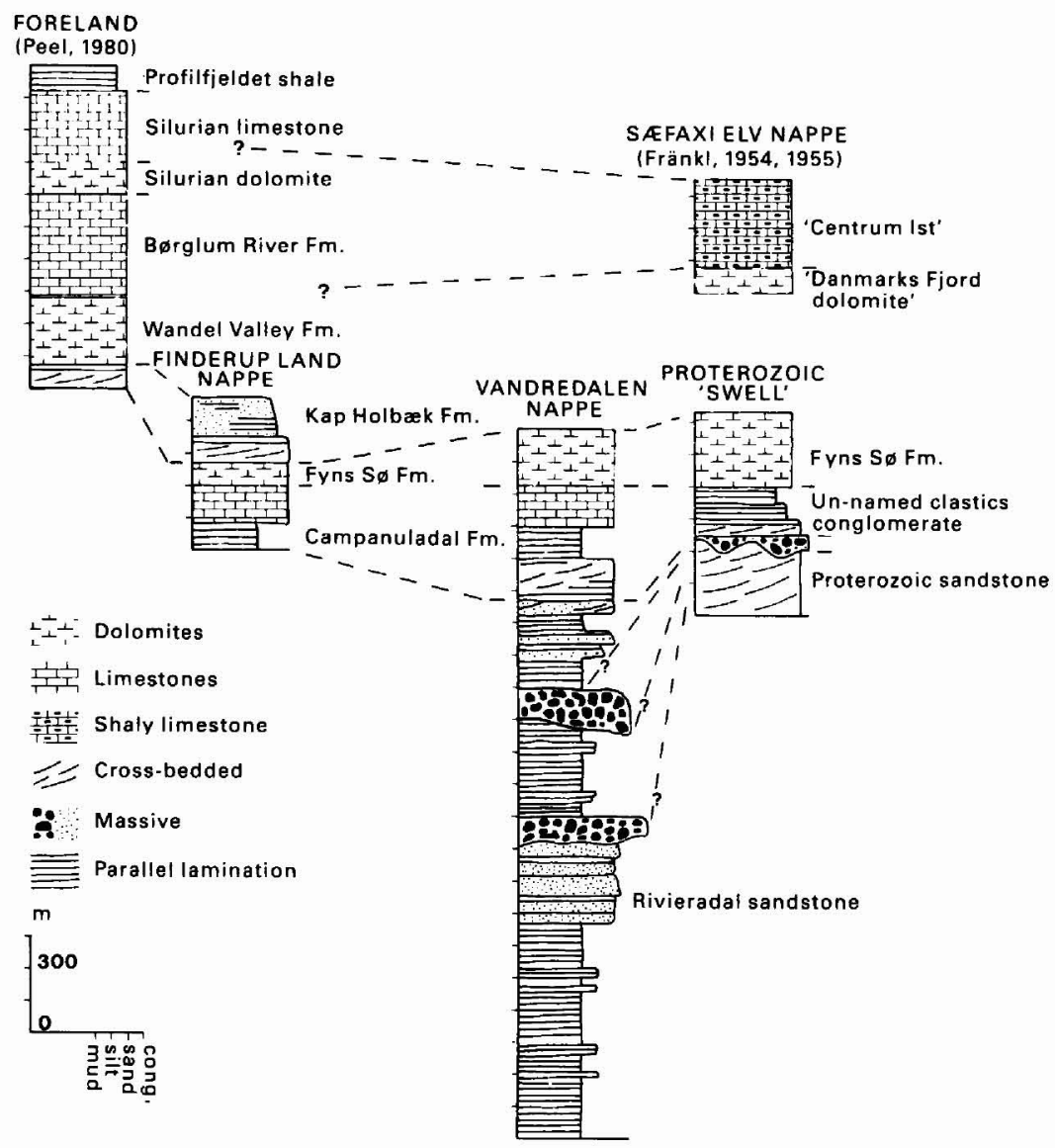

Fig. 5. Stratigraphy and facies distribution of the autochthonous (Foreland and Proterozoic 'Swell') and allochthonous (Finderup Land Nappe, Vandredalen Nappe and Sæfaxi Elv Nappe) sediments.

\section{Relationship between the nappes}

In southern Kronprins Christian Land, the relationships between the nappes are clearly exposed. To the south-east, near Marmorvigen (C, fig. 4) and along the south-western side of Sæfaxi Elv, the Vandredalen Nappe rests on the Sæfaxi Elv Nappe. Both nappes are thrust over an autochthonous sequence of Proterozoic sandstones with overlying conglomerate and Fyns Sø Formation. In the north, the relationships of the nappes are less clear. Both the Vandredalen and Finderup Land Nappes are seen to lie above autochthonous Silurian platform carbonates and turbidites. The outcrop distribution suggests that the Vandredalen Nappe overlies the Finderup Land Nappe, but the region of overlap is largely obscured by ice. 


\section{Derivation of the nappes}

Fränkl $(1954,1955)$ derived his Main Nappe, i.e. Vandredalen Nappe, from east of the Prinsesse Caroline-Mathilde Alper (fig. 4). The presence of the Fyns Sø Formation stratigraphically above the Proterozoic sandstones in eastern Kronprins Christian Land (fig. 5) implies that the Vandredalen Nappe, which also includes Fyns Sø Formation, could not have been derived from any area which still has a normal capping of Fyns Sø Formation. It therefore must have been derived from a region to the east of the present Fyns Sø Formation outcrops above the Proterozoic sandstones of the Prinsesse Caroline-Mathilde Alper. It would seem probable that the autochthonous thick sedimentary sequences were deposited east of a swell formed by Proterozoic sandstones which were covered only thinly and locally by late Precambrian strata below the Fyns Sø Formation. This conclusion is also borne out by the generally deeper water facies present in the allochthonous sediments compared with their equivalents on the platform to the west and on the Proterozoic sandstone swell. We conclude that the sediments on all three nappes were deposited in deep marine areas to the east of the Prinsesse Caroline-Mathilde Alper (cf. Haller, 1971).

\section{References}

Fränkl, E. 1954: Vorläufige Mitteilung über die Geologie von Kronprins Christian Land (NE-Grönland). Meddr Grønland 116 (2), 85 pp.

Fränkl, E. 1955: Weitere Beiträge zur Geologie von Kronprins Christian Land (NE-Grönland). Meddr Grønland 103 (7), 35 pp.

Haller, J. 1970: Tectonic map of East Greenland (1:500 000). Meddr Grønland 171 (5), 286 pp.

Haller, J. 1971: Geology of the East Greenland Caledonides. 413 pp. London: Interscience.

Nielsen, E. 1941: Remarks on the map and geology of Kronprins Christian Land. Meddr Grønland 126 (2), $34 \mathrm{pp}$.

Peel, J. S. 1980: Geological reconnaissance in the Caledonian foreland of eastern North Greenland with comments on the Centrum Limestone. Rapp. Grønlands geol. Unders. 99, 61-72. 